\title{
TP53AIP1 Gene
}

National Cancer Institute

\section{Source}

National Cancer Institute. TP53AIP1 Gene. NCI Thesaurus. Code C121114.

This gene plays a role in the regulation of p53-induced apoptosis. 